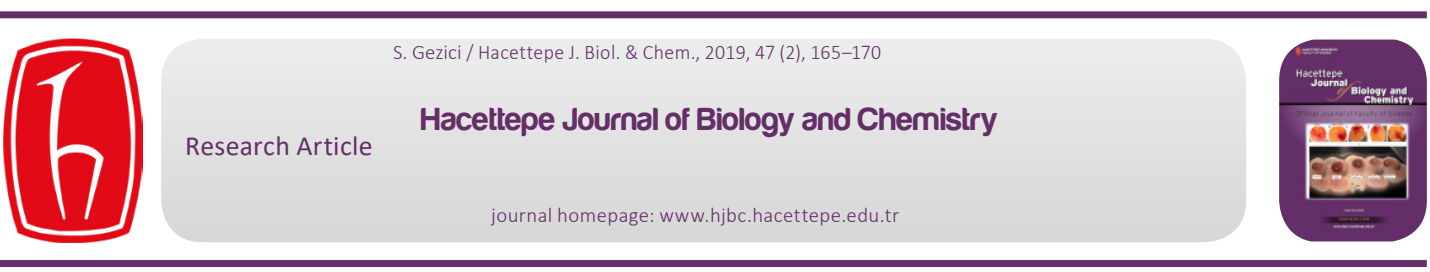

\title{
Neuroprotective Effect, Antimicrobial and Antioxidant Potentials of Sumac (Rhus coriaria L.) Fruit Extracts
}

\author{
Sumak (Rhus coriaria L.) Meyve Özütlerinin Nöroprotektif Etkisi, Antimikrobiyal ve \\ Antioksidan Potansiyelleri

\section{Sevgi Gezici ${ }^{\odot}$} \\ Dept of Molecular Bio. and Genetics, Advanced Technology Application and Research Center, Kilis 7 Aralık University, Kilis, Turkey.
}

\section{ABSTRACT}

\begin{abstract}
ntroduction: Rhus coriaria L. (sumac) is a traditional edible-plant in the Anatolia. The leaves and fruits of sumac have been extensively used in folk medicine and alternative therapeutic approaches, because of the presence of many bioactive phytochemicals. Material and Methods: In this study, we aimed to investigate in vitro neuroprotective, antimicrobial and antioxidant properties of sumac extracts that were extracted with water, methanol, $\mathrm{n}$-hexane, and dichloromethane. Results and Discussion: According to research results, almost all the tested extracts of sumac remarkable biological activities in a time and dose-dependent manner. Among the extracts, aqueous and methanolic extracts were demonstrated the highest cholinesterase inhibitory activity on both $\mathrm{AChE}$ and BChE enzymes, values ranging from $16.16 \pm 0.18$ to $41.08 \pm 0.02 \%$ at $200 \mu \mathrm{g} / \mathrm{mL}$ concentration. Regarding of MIC assay, all the extracts exhibited more growth-inhibitory effects against gramnegative bacteria strains than gram-positive bacteria strain, and MIC values in range of 3.9-62.5 $\mathrm{gg} / \mathrm{mL}$. In terms of DPPH radical scavenging activity, all the tested extracts demonstrated significant antioxidant capacity, methanol extract of sumac seemed to possess stronger scavenging activity $(56.11 \pm 1.08 \%$ at $100 \mu \mathrm{g} / \mathrm{mL}$ concentration) than the other extracts. Conclusion: These findings provide contributions to medicinal uses of sumac in nervous system disorders and microbial diseases as alternative therapeutic agents, along with traditional uses of sumac.
\end{abstract}

\section{Keywords}

Rhus coriaria L., neuroprotective, antimicrobial, antioxidant.

\section{öz}

iriş: Rhus coriaria L. (sumak) Anadolu'da geleneksel olarak yenilebilen bir bitkidir. Sumağın yaprak ve meyveleri birçok 3 biyoaktif fitokimyasalların varlığından dolayı, halk hekimliğinde ve alternatif tedavi yaklaşımlarında yaygın olarak kullanılmaktadır. Materyal ve Metot: Bu çalışmada; su, metanol, n-hekzan ve diklorometan ile ekstraksiyon yapılan sumağın nöroprotektif, antimikrobiyal ve antioksidan özelliklerinin belirlenmesi amaçlanıştır. Bulgular ve Tartışma: Araştırma sonuçlarına göre; test edilen sumak özütlerinin neredeyse tamamı, doz ve zamana bağlı olarak kayda değer bir şekilde

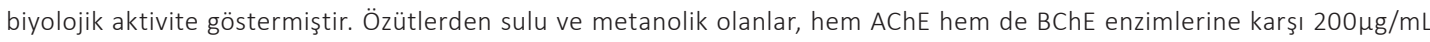
konsantrasyonda \%16.16 \pm 0.18 ile $41.08 \pm 0.02$ arasında değişen kolinesteraz inhibitör aktivite göstermiştir. Mik analizine ilişkin olarak, tüm özütler gram-negatif bakteri suşlarına karşı gram-pozitif bakteri suşlarından daha fazla büyüme engelleyici etki sergilemiştir ve MiK değerleri 3.9-62.5 $\mathrm{gg} / \mathrm{mL}$ aralığındadır. DPPH radikal süpürücü aktivite açısından; test edilen tüm özütler belirgin bir antioksidan kapasite göstermiş olup, metanol özütü diğer özütlerden $(\% 56.11 \pm 1.08,100 \mu \mathrm{g} / \mathrm{mL}$ konsantrasyonda) daha güçlü radikal süpürme aktivitesine sahip olduğu görülmektedir. Sonuç: Bulgular, sumağın geleneksel kullanımlarının yanı sıra; sinir sistemi bozukluklarında ve mikrobiyal hastalıklarda alternatif tedavi edici ajanlar olarak tıbbi kullanımlarına katkı sağlamaktadır.

\section{Anahtar Kelimeler}

Rhus coriaria L., nöroprotektif, antimikrobiyal, antioksidan.

Article History: Received: Nov 02, 2018; Revised: Jan 21, 2019; Accepted: Jan 25, 2019; Available Online: Sep 15, 2019.

DOI: $10.15671 /$ HJBC.621202

Correspondence to: S. Gezici, Department of Molecular Biology and Genetics, Kilis 7 Aralık University, Kilis, Turkey.

E-Mail: sevgigezici@kilis.edu.tr 


\section{INTRODUCTION}

r he genus Rhus (Anacardiaceae) is represented by approximately 300 species that distributing almost all over the world. Among Rhus species, Rhus coriaria Linn, also variously known as sumac, is a wild ediblemedicinal plant that is one of the most commonly used spice and appetizer in Turkey, Palestinia, Persia, Central and South-West Asia, Mediterranean and Middle East [1-3]. The plant grows in temperate and subtropical areas, and widespread throughout Mediterranean and Middle East regions, including Turkey, in where it grows natively in the Mediterranean and Southeastern Anatolia [4,5]. Historically, leaves and fruits of $R$. coriaria L. were also believed as being useful for prevention of diarrhea, diabetes, ulcer, liver diseases, hemorrhoids, obesity, colitis, fever, dermatitis and hyperglycemia in the Anatolian herbal medicine. Additionally, this plant were known to have remarkable medicinal values in the treatment of sore throat, reduction of stomach pains and cholesterol in folk medicine [4-7].

Researches about the biological activity of $R$. coriaria $L$. have been focused on the fruit and leaf parts of this herb. Previous in vivo and in vitro studies demonstrated that sumac possesses wide range of pharmacological properties, particularly anti-fibrogenic, anti-inflammatory, antimutagenic, hypoglycemic, anti-ischemic, antimalarial, antiviral, antimicrobial, antifungal, antioxidant, antiulcer, hepatoprotective, and atheroprotective, due to presence of many natural bioactive products and secondary metabolites, e.g. tannins, gallotannins, phenolic acids, gallic acids, anthocyanins, terpenoids quercetin, isoquercitrin, myricitrin, kaempferol, apigenin, luteolin etc., which are health-promoting natural components [8-13].

Besides its rich bioactive phytochemical compositions, $R$. coriaria $\mathrm{L}$. also has rich mineral contents such as Aluminum, Barium, Bromine, Calcium, Chlorine, Chrome, Copper, Iron, Magnesium, Manganese, Potassium, Lithium, Nitrogen, Nitrate, Phosphorus, Zinc, Silisium, Strontium, Lead, Titanium and Vanadium, of which, Calcium, Magnesium, Phosphorous, and Potassium are predominant elements found in sumac fruits $[14,15]$.

In view of the comprehensive pharmacological and phytochemical properties of sumac, scientists have confirmed sumac has a great importance in both nutritional and medicinal point of views. Even though biological activities of the extracts from $R$. coriaria
L. were demonstrated before, limited works have been undertaken for analyzing the neuroprotective potentials of the various extracts of sumac according to our knowledge. On the other hand, this is the first study that has been analyzed neuroprotective potentials of sumac extracts combined with antimicrobial and antioxidant activities using different assays.

\section{MATERIALS and METHODS}

\section{Collection and Authentication of Plant Material}

The fruits of $R$. coriaria $L$. were collected during the month of July 2017 from Kilis and Gaziantep, located in South-eastern part of Turkey. Plant material identified by $N$. Sekeroglu, and a voucher specimen (with number KIYUHERB085) was deposited in the herbarium of Biology Department at University of Kilis 7 Aralik, Turkey.

\section{Preparation of Crude Extracts}

Air-dried and powdered fruits of $R$. coriaria $\mathrm{L}$. (50 g) were extracted with $250 \mathrm{~mL}$ of different solvents including water, methanol (70\%), n-hexane and dichloromethane for 2 days at the room temperature. The extracts were filtered, and the methanol, n-hexane and dichloromethane phases were then removed by using a rotary evaporator (Sigma Aldrich, USA), while the water extracts were freezedried. All the extracts were stored at $+4^{\circ} \mathrm{C}$ until analyzed. Extraction yields of the water, methanol, $n$-hexane, and dichloromethane of the fruits were determined as $14.08 \%$, $9.20 \%, 5.13 \%$, and $1.85 \%$ (w/w\%), respectively.

\section{In vitro Enzyme Inhibitory Assays}

Neuroprotective activities of the extracts on AChE and BChE were evaluated by a slightly modified spectrophotometric method of Ellman et al. [16] Electric eel AChE (Type-VI-S, EC 3.1.1.7, Sigma, St. Louis, MO, USA) and horse serum BChE (EC 3.1.1.8, Sigma, St. Louis, MO, USA) were used, whereas acetylthiocholine iodide and butyrylthiocholine chloride (Sigma, St. Louis,MO, USA) were employed as substrates of the reaction, respectively. 5,5-Dithio-bis(2-nitrobenzoic) acid (DTNB, Sigma, St. Louis, MO, USA) was used for the measurement of the anticholinesterase activity. All reagents and conditions were same as described in our previous researches $[17,18]$. Percentage of inhibition of AChE/BChE was determined by comparison of rates of reaction of samples relative to blank (ethanol in phosphate buffer $\mathrm{pH}=8$ ). All the assays were carried out in triplicate, and galanthamine (Sigma, St. Louis, MO, USA) was used as the reference drug. 


\section{Microorganisms}

Antimicrobial activity was evaluated against to three bacterial organisms as Escherichia coli (ATCC 25322), Staphylococcus aureus (ATCC 6538), Pseudomonas aeruginosa (ATCC 15442), and one fungal organism as Candida albicans (ATCC 10231). Streptomycin (antibiotic) and Fluconazole (antimycotic) were used as positive controls. The bacterial strains were inoculated to Mueller Hilton Agar and Eosin Methylene-blue Lactose Sucrose Agar (MHA, EMB, Merck, Germany), and the fungal strain inoculated to Sabourand Dextrose Agar (SDA, Merck, Germany).

\section{In vitro Antimicrobial Activity}

Antimicrobial MIC (Minimum Inhibitory Concentration) assay was performed using the microdilution method in sterile 96 microplates by described Sarker et al. [19] previously. All the plates had positive controls: Streptomycin for bacteria and fluconazole for yeast with a concentration range of $0.49-1000 \mu \mathrm{g} / \mathrm{mL}$. The plates were conducted in triplicate for each organism, and incubated $37^{\circ} \mathrm{C}$ for $18-24 \mathrm{~h}$ for bacteria, while $30^{\circ} \mathrm{C} 48$ $\mathrm{h}$ for yeast.

\section{In vitro Antioxidant Assay}

Free radical scavenging activities of the sumac extracts were determined by microplate DPPH assay according to method described by Molyneux [20] and Gezici et al. [21] with some modifications. Firstly, each extract was solved in methanol with different concentrations starting from $12.5 \mu \mathrm{g} \cdot \mathrm{mL}^{-1}$ to $100 \mu \mathrm{g} \cdot \mathrm{mL}^{-1}$, and then diphenyl-2picryl-hydrazil (DPPH, Sigma Aldrich, St. Louis, MO, USA) was dissolved in methanol for preparation $1 \mathrm{mM}$ DPPH solution. Each well contained $200 \mu \mathrm{L}$ of extract solution and $1 \mathrm{~mL}$ of DPPH solution, the microplates were shaken gently and incubated at room temperature for $30 \mathrm{~min}$ in the dark, and then the absorbance value was read at $517 \mathrm{~nm}$ using a spectrophotometer in triplicate.

The inhibition of the DPPH scavenging activity was calculated as below:

DPPH scavenging activity in percentage $=\left(1-A_{517}\right.$ of sample / $A_{517}$ of control) $\times 100$, where $A_{\text {control }}$ is the absorbance of all the reagents except the test sample, $A$ is the absorbance of the extracts. Ascorbic acid was used as the standard antioxidant. A linear regression analysis was used to determine $\mathrm{IC}_{50}$ values (scavenge $50 \%$ of the DPPH radicals) of the extracts.

\section{Statistical Analysis}

All the assays were conducted in triplicate, and three different microplate wells were used for each concentration. The results were expressed as mean and standard deviation values (mean \pm SD). Statistical differences between the references and the sample groups were evaluated by ANOVA (one way). Correlations were carried out using the correlation and regression in the EXCEL programme. Differences between groups were considered as significant when a $P$-value was set at 0.05 , and very significant when a P-value was set at 0.01 .

\section{RESULTS and DISCUSSION}

\section{In vitro Enzyme Inhibitory Results}

The extracts obtained from the fruits of $R$. coriaria L. were also evaluated for their inhibitory activities on AChE and BChE at 25, 50, 100, and $200 \mu \mathrm{g} \cdot \mathrm{mL}^{-1}$ concentrations, using galanthamine as the reference drug are given in Table 1.

According to the results of enzyme inhibitory assays, sumac was found to have protective effects against the both of the enzymes at the tested concentrations, in which the water extracts of sumac were the most potent neuroprotector with the inhibition values of $28.62 \pm 1.04 \%(p<0.01)$ on AChE and $41.08 \pm 0.02 \%$ $(p<0.01)$ on BChE at $200 \mu \mathrm{g} \cdot \mathrm{mL}^{-1}$ (Table 1). On the other hand, the water extract exhibited the highest inhibitory activity, and the inhibitory activity of this extract was followed by methanol extract (16.16 \pm 0.18\% on AChE and $33.64 \pm 0.18 \%$ on $\mathrm{BChE}$ ). Among the tested extracts, the $n$-hexane extract was exerted $11.48 \pm 0.06 \%$ and $7.76 \pm 2.06 \%$ the lowest enzyme inhibition on AChE and $\mathrm{BChE}$, respectively. Additionally, the dichlorometane extracts of sumac remained inactive against the mentioned enzymes (Table 1).

As previously reported that antioxidants have neuroprotective and neuroregenerative functions, by reducing or reversing cellular damage and by slowing the progression of neuronal cell loss. Likewise, the combination of antioxidants activity and neuroprotective potentials of the herbal extracts is known to be associated with fighting neurodegenerative disorders such as such as optic neuropathies, glaucoma, Alzheimer's and Parkinson's diseases [17,21,22]. It can thus be argued that the neuroprotective activity 
Table 1. Inhibitory activity of the extracts against AChE and BChE at $200 \mu \mathrm{g} \cdot \mathrm{mL}^{-1}$.

\begin{tabular}{llc}
\hline Extract type & Acetylcolinesterase (AChE) & Butyrylcolinesterase (BChE) \\
& $($ Inhibition $\% \pm \mathrm{SD})$ & (Inhibition $\% \pm$ SD) \\
\hline Water & $28.62 \pm 1.04^{* *}$ & $41.08 \pm 0.02^{* *}$ \\
\hline Methanol & $16.16 \pm 0.18^{* *}$ & $33.64 \pm 0.18^{* *}$ \\
\hline $\mathrm{n}$-Hexane & $11.48 \pm 0.06^{*}$ & $7.76 \pm 2.06^{* *}$ \\
\hline Dichlorometane & $-^{b}$ & $-^{b}$ \\
\hline Galanthamine $^{\mathrm{b}}$ (at $\left.100 \mu \mathrm{gg} \cdot \mathrm{mL}^{-1}\right)$ & $90.18 \pm 1.04$ & $84.02 \pm 1.06$
\end{tabular}

The results are given as the mean value \pm standard deviation $(n=3)$.

a Galanthamine; reference for $\mathrm{AChE}$ and $\mathrm{BChE}$ inhibition.

${ }^{\mathrm{b}}$ No inhibitory activity.

${ }^{*} p$ value of $<0.05 ;{ }^{* *} p$ value of $<0.01$

of the sumac extracts correlates directly with the demonstrated presence of powerful free radical scavenging activity.

\section{In vitro Antimicrobial Results}

The results of antibacterial and antifungal activities for the extracts of R. coriaria L. fruits against E. coli, $P$. aeruginosa, $S$. aureus and $C$. albicans were summarized in Table 2.

Alltheextracts of sumac demonstrated moreinhibitory effects against gram-negative bacteria strains (E. coli and P. aeruginosa) than gram-positive bacteria (S. aureus) in terms of bacterial growth. Our results are compatible with previous reports that gram-negative strains were found more sensitive than gram-positive bacteria strains [23,24]. However, the lowest antibacterial activity was determined with the dichloromethane extracts of $R$. coriaria $\mathrm{L}$. against almost all bacteria strains with 62.5 and $>1000 \mu \mathrm{g} / \mathrm{mL}$ MIC value, the methanol extracts of $R$. coriaria $\mathrm{L}$. demonstrated high growth inhibitory effects against both gram-negative and gram-positive microorganisms from 3.9 to 62.5 $\mu \mathrm{g} . \mathrm{mL}^{-1} \mathrm{MIC}$ value. Among all other bacteria strains, the highest antibacterial activity was found against $E$. coli with MIC values of $3.9 \mu \mathrm{g} / \mathrm{mL}$, while, the lowest antibacterial activity was found against $S$. aureus, with MIC values of $500 \mu \mathrm{g} / \mathrm{mL}$, in comparison to streptomycin (MIC= 0.49$3.90 \mu \mathrm{g} / \mathrm{mL}$ ) as a positive control. Although, the extracts of sumac showed stronger antibacterial activities to all tested strains, they had middle antifungal activity to $C$. albicans, among the extracts the methanol and water extracts showed more anti-yeast activity than the other extracts with $62.25 \mu \mathrm{g} \cdot \mathrm{mL}^{-1}$ and $250 \mu \mathrm{g} / \mathrm{mL}$ MIC value, comparing with fluconazole $(\mathrm{MIC}=1.95 \mu \mathrm{g} / \mathrm{mL}$ ) as positive control. The antimicrobial potential of the extracts of sumac can be presented as methanol > water $>n$-hexane $>$ dichloromethane. The methanol extracts of sumac proved to be the most potent one; MIC values range for 3.9-62.25 $\mu \mathrm{g} / \mathrm{mL}$ for bacteria strains and $62.25 \mu \mathrm{g} . \mathrm{mL}^{-1}$ for yeast. These results indicate that most of flavonoids and derivatives such as myricetin, quercetin, kaempferol etc. as well as terpenes such as carvacrol, $\alpha$-terpineol, $\beta$-caryophyllene alcohol etc. found in sumac may possess good potential as antimicrobial agents $[1,25,26]$.

Table 2. Antibacterial and antifungal activities of the extracts of $R$. coriaria L. as MIC $\left(\mu \mathrm{g} \cdot \mathrm{mL}^{-1}\right)$ values.

\begin{tabular}{lllll}
\hline \multirow{2}{*}{ Sumac Extracts } & \multicolumn{4}{c}{$\mathrm{MIC}\left(\mu \mathrm{\mu g} \cdot \mathrm{mL}^{-1}\right)$} \\
\cline { 2 - 5 } & E. coli & P. aeruginosa & S. aureus & C. albicans \\
\hline Water & 7.81 & 31.25 & 125 & 250 \\
\hline Methanol & 3.9 & 15.62 & 62.25 & 62.25 \\
\hline $\mathrm{n}$-Hexane & 31.25 & 62.5 & 250 & 500 \\
\hline Dichloromethane & 62.5 & 125 & 500 & $>1000$ \\
\hline Streptomycin $^{\mathrm{a}}$ & 0.49 & 1.95 & 3.90 & ${ }^{c}$ \\
\hline Fluconazole $^{b}$ & $-{ }^{c}$ & $-{ }^{c}$ & $-{ }^{c}$ & 1.95 \\
\hline
\end{tabular}

All the data are presented as the mean values of triplicates for each microorganism $(n=3)$.

a Streptomycin; standard antibiotic, positive control.

b Fluconazole; standard antimycotic, positive control.

${ }^{\mathrm{c} N o}$ inhibitory activity. 
Table 3. DPPH radical scavenging activity (\%) of the extracts from $R$. coriaria $\mathrm{L}$.

$\%$ Inhibition of DPPH \pm SD

\begin{tabular}{|c|c|c|c|c|}
\hline Extracts & $12.5 \mu \mathrm{g} \cdot \mathrm{mL}^{-1}$ & $25 \mu \mathrm{g} \cdot \mathrm{mL}^{-1}$ & $50 \mu \mathrm{g} \cdot \mathrm{mL}^{-1}$ & $100 \mu \mathrm{g} \cdot \mathrm{mL}^{-1}$ \\
\hline Water & $20.42 \pm 0.03 * *$ & $23.01 \pm 0.03 *$ & $26.72 \pm 0.05^{* *}$ & $42.02 \pm 1.01^{*}$ \\
\hline Methanol & $21.34 \pm 0.04^{*}$ & $30.58 \pm 0.04^{*}$ & $39.98 \pm 0.07^{* *}$ & $56.11 \pm 1.08^{* *}$ \\
\hline n-Hexane & $18.37 \pm 0.03^{*}$ & $20.02 \pm 0.05^{* *}$ & $2.47 \pm 0.07 * *$ & $35.95 \pm 0.08^{*}$ \\
\hline Dichloromethane & $16.12 \pm 0.02^{* *}$ & $19.13 \pm 0.04^{* *}$ & $22.35 \pm 0.06^{* *}$ & $29.47 \pm 0.06 * *$ \\
\hline$A A^{a}$ & $23.21 \pm 0.03$ & $25.43 \pm 0.03$ & $30.96 \pm 0.06$ & $45.48 \pm 1.20$ \\
\hline
\end{tabular}

The results are given as the mean value \pm standard deviation $(n=3)$, and the data are expressed as percentage of inhibition

${ }^{a} A A ;$ Ascorbic acid, commercial standard

${ }^{*} p$ value of $<0.05 ;{ }^{* *} p$ value of $<0.01$

\section{In vitro Antioxidant Results}

The potential antioxidant activities of the extracts obtained from sumac were determined by DPPH radical scavenging assay. The DPPH activity results of the extracts at different concentrations starting from 12.5 $\mu \mathrm{g} \cdot \mathrm{mL}^{-1}$ to $100 \mu \mathrm{g} \cdot \mathrm{mL}^{-1}$ were shown in Table 3 and the values were compared with ascorbic acid.

According to data presented in Table 3, all the extracts of sumac showed powerful superoxide radical scavenging and antiradical activities against DPPH in a concentration-dependent manner and significantly different $(p<0.01)$ by when compared with ascorbic acid, a commercial standard antioxidant. The high DPPH radical scavenging activity determined for the methanol extract as $56.11 \pm 1.08 \%(p<0.01)$ at $100 \mu \mathrm{g} \cdot \mathrm{mL}^{-1}$ concentration. It is followed by the water and $n$-hexane extracts $42.02 \pm 1.01 \%$ and $35.95 \pm 0.08 \%(p<0.05)$ at $100 \mu \mathrm{g} \cdot \mathrm{mL}^{-1}$ concentration, respectively. In this assay, dichloromethane extract showed the weakest scavenging activity. The values obtained from DPPH assay are comparable with wellknown antioxidant, AA (45.48 $\pm 1.20 \%)$ which was used as positive control.

The anthocyanin, hydrolyzable tannins and gallic acid derivatives found in sumac most likely to be responsible for powerful antioxidant activity. It is probably that the extracts of sumac inhibit the production of reactive oxygen spices that have potential to damage cells, and the degradation of nucleic acids and other organic compounds are prevented by the polyphenolic active constituents of $R$. coriaria L. $[3,8,10,26]$.

\section{CONCLUSIONS}

Consequently, different sumac extracts have shown significant effects on decreasing growth of microorganisms and inhibition of the AChE and BChE enzymes, which are linked to neurodegenerative disorders. As can be seen from the data presented in this research, the extracts have been found to have strong neuroprotective and antioxidants effects in a time and concentration dependent manner, even at lower concentration and minimum exposure time. These findings suggest the consumption of sumac has the potential in the prevention of some disorders as natural sources for antioxidant, antimicrobial, as well as enzyme inhibitory agents. The obtained results could support the widespread uses of sumac in health, nutrition, and pharmacology and as a source of functional ingredients. Additional studies should be conducted to identify which bioactive phytochemical(s) are responsible for these wide ranges of biological effects actually, and should be investigated the molecular mechanisms underlying the potential effects of sumac.

\section{Acknowledgments}

The author gratefully acknowledges the support and technical assistance of the Kilis 7 Aralık University, Central Laboratory. The author would like to thank Prof. Dr. Nazim Sekeroglu for his kind contribution of collecting and identifying the plant material. The abstract of the manuscript had been presented as an oral presentation in The Third International Mediterranean Symposium on Medicinal and Aromatic Plants (MESMAP-3) in Girne-T.R.N.C. in 2017.

\section{Conflict of interests}

There is no conflict of interest.

\section{References}

1. S. Rayne, G. Mazza, Biological activities of extracts from sumac (Rhus spp.): a review, Plant Foods Hum. Nutr., 62 (2007) 165-175.

2. A. Shabbir, Rhus coriaria linn, a plant of medicinal, nutritional and industrial importance: a review, J. Anim. Plant. Sci., 22 (2012) 505-512. 
3. S.T. Rahideh, F. Shidfar, N. Khandozi, A. Rajab, S.P. Hosseini, \& S.M. Mirtaher, The effect of sumac (Rhus coriaria L.) powder on insulin resistance, malondialdehyde, high sensitive C-reactive protein and paraoxonase 1 activity in type 2 diabetic patients, J. Res. Med. Sci.: the official journal of Isfahan University of Medical Sciences, 19 (2014) 933.

4. S. Giancarlo, L.M. Rosa, F. Nadjafi, M. Francesco, Hypoglycaemic activity of two spices extracts: Rhus coriaria L. and Bunium persicum Boiss.. Nat. Prod. Res., 20 (2006) 882-886.

5. B. Moyo, S. Mukanganyama, Antiproliferative activity of $T$. welwitschii extract on Jurkat T cells in vitro, BioMed. Res. Int., 2015 (2015) 1-10.

6. E. Lev, Z. Amar, "Fossils" of practical medical knowledge from medieval Cairo, J. Ethnopharmacol., 119 (2008) 24-40.

7. S. Mohammadi, S.M. Kouhsari, A.M. Feshani, Antidiabetic properties of the ethanolic extract of Rhus coriaria fruits in rats. Daru: journal of Faculty of Pharmacy, Tehran University of Medical Sciences, 18 (2010) 270.

8. A. Panico, V. Cardile, N.A. Santagati, R. Messina, Antioxidant and protective effects of sumac leaves on chondrocytes, J. Med. Plant. Res., 3 (2009) 855-861.

9. K.B. Pandey, S.I. Rizvi, Plant polyphenols as dietary antioxidants in human health and disease, Oxid. Med. Cell. Longev., 2 (2009) 270-278.

10. J. Pourahmad, M.R. Eskandari, R. Shakibaei, M. Kamalinejad, A search for hepatoprotective activity of aqueous extract of Rhus coriaria L. against oxidative stress cytotoxicity, Food. Chem. Toxicol., 48 (2010) 854-858.

11. M.M. Shabana, A.M. El Sayed, M.F. Yousif, A.M. El Sayed, A.A Sleem, Bioactive constituents from Harpephyllum caffrum Bernh. and Rhus coriaria L. Pharmacogn Mag., 7 (2011) 298.

12. F. Shidfar, S.T. Rahideh, A. Rajab, N. Khandozi, S. Hosseini, S. Shidfar S, et al. The Effect of sumac (Rhus coriaria L.) Powder on Serum Glycemic Status, ApoB, ApoA-I and Total Antioxidant Capacity in Type 2 Diabetic Patients, Iran. J. Pharm. Res., 13 (2014) 1249

13. M.A Anwar, A.A. Samaha, S. Baydoun, R. Iratni, \& A.H. Eid, Rhus coriaria Evokes Endothelium-Dependent Vasorelaxation of Rat Aorta: Involvement of the CAMP and cGMP pathways, Front. Pharmacol., 9 (2018) 688.

14. M. Özcan, H. Haciseferogullari, A condiment [sumac (Rhus coriaria L.) fruits]: some physicochemical properties, Bulgar. J. Plant. Physiol., 30 (2004) 74-84.

15. S. Akgunlu, N. Sekeroglu, U. Koca-Caliskan, F. Ozkutlu, B. Ozcelik, M. Kulak, S. Gezici, Research on selected wild edible vegetables: Mineral content and antimicrobial potentials, Ann. Phytomed., 5 (2016) 50-57.
16. G.L. Ellman, K.D. Courtney, V. Andres Jr, R.M. Featherstone, A new and rapid colorimetric determination of acetylcholinesterase activity, Biochem. Pharmacol., 7 (1961) 88-95.

17. F.S. Şenol, N. Şekeroğlu, S. Gezici, E. Kiliç, I.E. Orhan, Neuroprotective potential of the fruit (acorn) from Quercus coccifera L., Turk. J. Agric. For., 42 (2018) 82-87.

18. S. Gezici, N. Sekeroglu, Neuroprotective potential and phytochemical composition of acorn fruits, Ind. Crop. Prod., 128 (2019) 13-17.

19. S.D. Sarker, L. Nahar, Y. Kumarasamy, Microtitre plate-based antibacterial assay incorporating resazurin as an indicator of cell growth, and its application in the in vitro antibacterial screening of phytochemicals, Methods., 42 (2007) 321-324.

20. P. Molyneux, The use of the stable free radical diphenylpicrylhydrazyl (DPPH) for estimating antioxidant activity, Songklanakarin J. Sci. Technol., 26 (2004) 211-219.

21. S. Gezici, N. Sekeroglu, A. Kijjoa, In vitro Anticancer Activity and Antioxidant Properties of Essential Oils from Populus alba L. and Rosmarinus officinalis L. from South Eastern Anatolia of Turkey, Ind. J. Pharma. Edu. Res., 51 (2017) 498503.

22. N. Sekeroglu, E. Urlu, M. Kulak, S. Gezici, R. Dang, Variation in Total Polyphenolic Contents, DNA Protective Potential and Antioxidant Capacity from Aqueous and Ethanol Extracts in Different Plant Parts of Hypericum perforatum L., Ind. J. Pharma. Edu. Res., 51 (2017) 1-7.

23. A. Sokmen, B.M. Jones, M. Erturk, The in vitro antibacterial activity of Turkish medicinal plants, J. Ethnopharmacol.. 67 (1999) 79-86.

24. S. Nasar-Abbas, A.K. Halkman, Antimicrobial effect of water extract of sumac (Rhus coriaria L.) on the growth of some food borne bacteria including pathogens, Int. J. Food Microbiol., 97 (2004) 63-69.

25. M. Mehrdad, M. Zebardast, G. Abedi, M.N. Koupaei, H. Rasouli, M. Talebi, Validated high-throughput HPLC method for the analysis of flavonol aglycones myricetin, quercetin, and kaempferol in Rhus coriaria L. using a monolithic column, J. AOAC Int., 92 (2009) 1035-1043.

26. I.M. Abu-Reidah, M.S. Ali-Shtayeh, R.M. Jamous, D. ArráezRomán, A. Segura-Carretero, HPLC-DAD-ESI-MS/MS screening of bioactive components from Rhus coriaria L.(Sumac) fruits, Food Chem., 166 (2015) 179-191. 